\title{
NRTIs (ZDV and d4T) side effects in PLHAs attending the antiretroviral treatment centre of B. J. Medical College Aad Civil Hospital At Ahmedabad, Gujarat, India
}

\author{
Umesh Nihalani, Asha Shah, Burzin Kavina, Bipin Amin, Urvi Derasari, Hemang Purohit, Bankim Mankad, \\ Sanjeev Prajapati, Girish Prajapati, Manoj Shevkani*
}

From $16^{\text {th }}$ International Symposium on HIV and Emerging Infectious Diseases Marseille, France. 24-26 March 2010

\section{Background}

This study reviews common side effects experienced by PLHAs who were initiated with Zidovudine or Stavudine based FDC ART regimen as per Indian National ART Guidelines attending ART Centre of B. J. Medical College and Civil Hospital, Ahmedabad, Gujarat, India.

\section{Methods}

All the ICTC confirmed HIV Positive Patients were registered and initiated with FDC ART at ART Center of the Institute as per Indian National ART Guidelines; recommends the use of 2 NRTIs (ZDV/d4T +3 TC) +1 NNRTI (EFV/NVP). Baseline parameters like CD4 count, necessary laboratory investigations, TB Workup and adherence counseling were carried out and on follow up. Depending on the level of hemoglobin NRTIs were chosen.

\section{Results}

Total 4379 patients were studied during the period of May 2005 to November 2008 initiated with either ZDV or $\mathrm{d} 4 \mathrm{~T}$ based ART regimen. Out of them total 3355 (76.62\%) were on either ZDV or d4T based ART regimen and regular visitor of the ART Centre are the study target, while the remaining 1024 (23.38\%) were either lost to follow up (LFU), expired and transferred out were excluded, Table 1.
Table 1

\begin{tabular}{clcc}
\hline ART Regimen & \multicolumn{1}{c}{ Side Effect } & No. of Patients & $\%$ \\
\hline $\begin{array}{c}\text { ZDV } \\
\mathrm{n}=1538 \\
45.85 \%\end{array}$ & Anemia & 212 & $13.78 \%$ \\
$\begin{array}{c}\mathrm{d} 4 \mathrm{~T} \\
\mathrm{n}=1817 \\
54.16 \%\end{array}$ & Peripheral Neuropathy & 220 & \\
& & & \\
& Dyslipidaemias & $12.11 \%$ \\
& Lipoatrophy & 108 & $7.87 \%$ \\
& Lactic acidosis & 6 & $0.34 \%$ \\
& Pancreatitis & 5 & $0.27 \%$ \\
\hline & & &
\end{tabular}

Few patients $15(0.83 \%)$ had multiple side effects, while in remaining $71(3.91 \%)$ the exact reason for regimen change was not available.

\section{Discussion}

The most observed side effects after initiating ART; Anemia (ZDV based) and Peripheral Neuropathy (d4T based) requires regular monitoring for early diagnosis. Substitution within same group must be done. While ART is becoming increasingly effective; side effects are low compared to studies in India and Cambodia by Sharma et. al., 2008 (Anemia 20.0\%, Peripheral Neuropathy 22.2\%) and Isaakidis et.al., 2008 (Anemia 21.92\%).

\footnotetext{
* Correspondence: coe.art.ahmedabad@gmail.com
}

ART center B J Medical College, Ahmedabad, India 
To optimize adherence and hence efficacy, clinicians must focus on preventing side effects whenever possible to yield the overall successfulness to the National Program.

Published: 11 May 2010

\section{doi:10.1186/1742-4690-7-S1-P65}

Cite this article as: Nihalani et al:: NRTIs (ZDV and d4T) side effects in PLHAs attending the antiretroviral treatment centre of B. J. Medical

College Aad Civil Hospital At Ahmedabad, Gujarat, India. Retrovirology 2010 7(Suppl 1):P65.

Submit your next manuscript to BioMed Central and take full advantage of:

- Convenient online submission

- Thorough peer review

- No space constraints or color figure charges

- Immediate publication on acceptance

- Inclusion in PubMed, CAS, Scopus and Google Scholar

- Research which is freely available for redistribution

Submit your manuscript at www.biomedcentral.com/submit 